УДК 004.514, 004.42

\title{
Information Support Technique \\ for Solving Agricultural Land Monitoring Tasks Based on Earth Remote Sensing Data
}

\author{
Ruslan V. Brezhnev and Yuriy A. Maglinets* \\ Siberian Federal University \\ 79 Svobodny, Krasnoyarsk, 660041, Russia
}

Received 04.04.2017, received in revised form 12.06.2017, accepted 20.07.2017

The article is dedicated to end users (decision makers) of information support technique in the process of agricultural lands' $(A L)$ remote monitoring with the use of Earth remote sensing (ERS) data. The model of spatial object has been developed, which considers its spatial structure and allows to estimate its state in accordance with preset plan of object development with time.

Keywords: Earth remote sensing data, spatial object model, spatial inhomogeneity, NDVI, agricultural lands, end user, web-GIS, phenophase, agricultural land monitoring, agro-technological measure.

Citation: Brezhnev R.V., Maglinets Yu.A. Information support technique for solving agricultural land monitoring tasks based on earth remote sensing data, J. Sib. Fed. Univ. Eng. technol., 2017, 10(6), 819-827. DOI: 10.17516/1999-494X-2017-10-6-819827.

(C) Siberian Federal University. All rights reserved

* Corresponding author E-mail address: brejnev.ruslan@gmail.com 


\title{
Методика информационной поддержки
}

\section{решения задач агромониторинга}

\section{по данным дистанционного зондирования Земли}

\author{
Р.В. Брежнев, Ю.А. Маглинец \\ Сибирский федеральный университет \\ Россия, 660041, Красноярск, пр. Свободный, 79
}

\begin{abstract}
Представлена методика информационной поддержки конечных пользователей (лии, принимающих решения) в процессе дистанционного мониторинга земель сельскохозяйственного назначения с использованием открытых данных дистанционного зондирования Земли. Разработана модель пространственного объекта, учитывающая его пространственную структуру и позволяющая оценивать его состояние в соответствии с заданным планом его развития во времени.
\end{abstract}

Ключевые слова: данные дистанционного зондирования Земли, модель пространственного объекта, пространственная неоднородность, NDVI, земли сельскохозяйственного назначения, конечный пользователь, web-ГИС, фенофаза, агромониторинг, агротехнологическое мероприятие.

\section{Introduction}

The tasks of space monitoring of spatial objects are solved in a whole range of practical applications: during emergency monitoring, construction, in oil and gas industry, agricultural industry, etc. Image-processing application packages (ENVI, Erdas Imagine, Scanex Imgae Processor, etc.), as well as general purpose geo-information systems (QGis, ArcGis, etc.) and specific purpose ones (e.g., ActiveMap, "Agriculture", Scanex "KosmosAgro") are used as tools for solving such tasks. It is worth mentioning that above-mentioned software tools are designed for specialists in the sphere of geospatial data processing and analysis, while solutions adapted for support of the end user, specialist in a specific subject area, remain underdeveloped. The author considers development of information environment for interaction between end user - agricultural specialist and automated system of agricultural land remote monitoring during setting and solving agricultural land (hereinafter referred to as $\mathrm{AL}$ of "field") monitoring tasks.

\section{Problem statement}

Study subject is a spatial object - agricultural land. Obvious characteristic of this object is its contour shape. Rectangular shape of the fields with 1:2 aspect ratio is considered to be the best one, or trapeze with min. $60^{\circ}$ tapered side angle. If the field has irregular shape, labour productivity deceases, the number of machinery idle runs grows, as well as fuel consumption, all this leads to increase in crop growing cost ratio. In reality, standard shape is not always achieved during field layout. So, agricultural landscapes of Krasnoyarsk Krai are often characterized by small contours, outliers, complex boundaries, small square (less than $100 \mathrm{ha}$ ). Next approximation of considered concept if the term "agricultural area" [1-2], i.e., land within agricultural boundaries with homogeneous vegetation.

Apart from shape characteristics, studied spatial object has a vector of iconic features: spectral, textural, metric, topological, etc. During vegetation the field is subject to different influences stipulated 
by both natural trends and anthropogenic (technogenic) factor. This results in the change in observed features vector, moreover, some features can be dynamically added to the formed model, by emerging at a given time.

Moreover, during object modelling one more factor shall be considered: due to natural and anthropogenic reasons different components of the studied object evolve in many ways. This explains inhomogeneity of the object structure, and inhomogeneity character is also variable with time.

Detection of local object inhomogeneities using satellite images allows to estimate uniformity of crop emergence, its degradation, as well as the level of fulfillment of the planned agro-technological measures. However, carried out literature review [3-5] showed that the issues of local spatial inhomogeneities analysis during organization of spatial object monitoring systems haven't been sufficiently addressed so far.

\section{Conceptual model of spatial object "AL"}

The object is characterized by the following groups of characteristics significant for organization of monitoring system.

1) Spatial localization (precise geographical coordinates of the object, with account of topological peculiarities).

2) Name and variety of the crop of the current field season.

3) Seasonal vegetation process schedule as evidenced by the change of crop phenological phases.

4) Possible abnormalities (in connection with phenological phases), such as non-emergence, soil overwetting, drought, infestation, etc.

5) Technogenic burden, represented by planned and implemented agro-technological measures (ATM).

6) Crop characteristics (such as integral state, biomass, leaf area, etc.).

Principal goals of agricultural land monitoring are observation of seasonal vegetation process, localization of abnormal manifestations, tracing of ATM and their results.

Every individual crop $K_{i}$ correlates with the model of its development in time under the influence of natural and technogenic factors in the form of state-transition diagram $G_{i}$ (see Fig. 1):

$$
G_{i}=<F, R>\text {, }
$$

where $F=\left\{f_{i}\right\}-$ a set of field states, $R-$ a set of state transitions;

$$
R=R^{1} \cup R^{2} \cup R^{3},
$$

$R^{1}$ - set of operators, which describe time sequencing (natural phenophase change), $R^{2}$ - set of operators, which describe abnormal phenomena in vegetation community development, $R^{3}-$ set of operators, which simulate ATM implementation. The state can be simple (plant phenophase) and composite (significant changes within one phenophase). Every state is characterized by a set of features described above.

From the point of aerospace monitoring organization, it is important to single out a set of features, detected on the object digital images, and find connection between the values of observed features on the image, on the one part, and $F$ set elements, on the other part. 


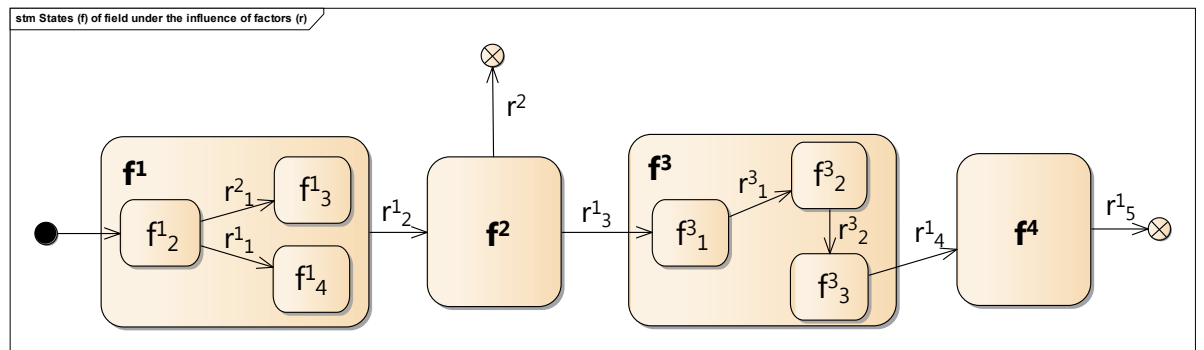

Fig. 1. A model of monitoring object change in time under the influence of natural and technogenic factors

The article considers the case when an observed object is fixed in space (spatial boundaries of agricultural contour are precisely known). Such assumption is explained by the fact that field boundaries have low variability in time, as they are limited by natural barriers (topographic inequalities, roads, population center limits, waters, utilities, trees and shrubs, etc.), as well as established history of use and cadastral division of territories.

After fixing field boundaries during monitoring task setting, it is necessary to determine spectral and textural image features inside the contour essential for monitoring organization. Red, nir, green, blue channels and their combinations (e.g., NDVI, PVI, EVI, SAVI indices, etc.) are useful for analysis of vegetation communities characteristics. Textural features can be additionally integrated on high detail images.

In general, image area $s_{i}$, which is interpreted as a field in the context of above-stated limitations, is characterized by vector of iconic features $X=\left\{x_{i}\right\}$. The value of individual feature is an average numeric value with respect to all pixel values relating to field. Researches carried out in papers $[6,7]$ show high correlation between measurements on the images and vegetation cover properties. This allows to define $g$ reference function synthesis problem, which compares $s_{i}$ image location in multidimensional feature space and observed AL state $f_{j}$.

All above-stated refers to image areas with homogeneous structure. However, studies of vegetation dynamics on the fields of Sukhobuzimsky District of Krasnoyarsk Krai (about 1500 fields in the period from 2013 to 2016) showed that only $30 \%$ of agricultural contours exhibit homogeneity property throughout the entire vegetation season.

For $s_{i}$, characterized by internal inhomogeneity, before carrying out interpretation of the state of the field corresponding to the images, it is necessary to perform $s_{i}$ segmentation in $w_{j}$ area, which meets homogeneity criteria. In contrast to $s_{i}$, which space coordinates are fixed, $w_{j}$ position in space requires localization. Moreover, feature vector $X$, made for $w_{j}$, apart from iconic features, it is necessary to include geometrical characteristics, which physical interpretation shows position and shape of inhomogeneities within the field.

To summarize, during AL description as a spatial object, homogeneous and inhomogeneous objects shall be distinguished. The former are characterized by spatial and time coordinates, vector of informative iconic features $X$ and reference function $g$, which allows to interpret AL state based on GPS survey data. For the second group of objects it is necessary to additionally find segmentation into homogeneous areas, each of them characterized by the same features as the first group objects and, in addition, a set of geometrical characteristics. 
Type representation has been developed on the basis of conceptual model:

$$
M_{O}=<K, I D, A, N, T>
$$

where $K$ is object contour coordinates, $I D$ is object identifier or field number, $A$ is a vector of values of geometrical features, $N$ is a vector of values of iconic features, $T$ is a measurement time. This representation is the basis for object-relational model of AL object in the system.

\section{Organization of a dialogue for remote monitoring task setting for end user}

Remote monitoring task setting is considered as a task of generation and resolution of information inquiries on the current (actual) state of the studied objects observed on satellite image. Due to the focus on end user (EU), technique shall ensure the following possibilities:

- Means of organization of a dialogue for information inquiry generation, which must provide for EU minimum number of steps in the process of object initial state building up, specifying only that information in which EU is competent.

- Information inquiry resolution scheme, which, in general, involves search for current satellite data, its processing and analysis.

- Means of organization of a dialogue for information inquiry results assessment, which must visualize to the user current state of the object $\left(S_{f}\right)$ with account of its structure.

The dialogue for information inquiry generation starts with EU authorization process, followed by automatic identification of agricultural producer by the system and display of the boundaries of the fields used by him for EU. Moreover, the map of agricultural contours of the enterprise is displayed.

EU has a possibility of specifying monitoring area by localizing the object or a group of objects in space by means of multiple selection of their contours (Fig. 2a)). In other words, EU generates information inquiry in the system, assigning initial set of features, which allow the system to localize precisely monitoring area $-\left\{k_{j}, t_{i}, i d_{i}\right\}, k_{i} \in K, t_{i} \in T, i d_{i} \in I D$.

In response to the inquiry, the system determines the necessary elements of the vectors $A, N$ of the model (3), which shall be calculated and updated; the relevant calculations are performed.

Then the system offers to carry out time localization of the object. EU can set a precise point of time localization for update of the object state, or initiate scheduled update in automatic mode. The schedule is based on the model (1). The system considers timeframe of planned events and activates generation of information inquiry. At the same time EU has a possibility of changing localization of data update point, and, accordingly, influence the process of object model update.

\section{End user information inquiry resolution algorithm}

The algorithm solves the problem of EU information inquiry resolution on the current state of spatial objects. Algorithm preconditions are completion of initial feature space generation in above-described dialogue between EU and automatic system. Let's consider main steps of the algorithm.

Obtaining ERS data from open sources [8, 9]. United States Ground Survey - USGS resource, where Landsat, Aqua, Terra, Sentinel, etc. programs' data are published, is used as ERS data source.

$$
-823-
$$


Algorithm description is displayed in the example of Landsat- 8 data search, mastery and processing on a localized territory in automatic mode.

ERS data processing and interpretation. This process includes the following sequence of steps:

1. Unpack downloaded archive and extract Red $\left(\right.$ Band $\left._{R e d}\right)$ and NIR $\left(\right.$ Band $\left._{N I R}\right)$ channels for NDVI calculation.

2. Combine Band $_{\text {Red }}$ and Band $_{N I R}$ and save as a single image in GeoTIFF format.

3. Open quality channel $\left(\right.$ Band $\left._{B Q A}\right)$ and represent it as a two-dimensional array.

4. Determine non-informative image pixels and represent them as a two-dimensional array.

5. Delete non-informative pixels of the channels $\operatorname{Band}_{R e d}$ и $\operatorname{Band}_{N I R}: \operatorname{Band}_{R E D}[\mathrm{row}, \mathrm{col}]=0$, $\operatorname{Band}_{N I R}[$ row, col $]=0$. Deletion occurs by deduction of a set of pixels of $\operatorname{Band}_{B Q A}$ channel, represented as a two-dimensional array from a set of pixels of $B a n d_{R e d}$ and $B a n d_{N I R}$ channels, also represented as two-dimensional arrays: $A_{\text {Red }} \backslash A_{B Q A}, A_{N I R} \backslash A_{B Q A}$. This allows to improve the process of object pixel structure analysis.

6. Crop the image by a set vector mask of the objects. Cropping allows to receive image segment which corresponds to predefined object. This step reduces volume and time of image processing by processing only segment of interest.

7. Calculate spectral features - vegetation index NDVI based on the obtained image:

$$
N D V I=\frac{N I R-R e d}{N I R+R e d},
$$

where NIR is a near infrared band, and Red means red colour. As a result image channel with the values NDVI $\left(\right.$ Band $\left._{N D V I}\right)$ is created (Fig. $\left.2 b\right)$.

8. Analyze object texture. Segmentation of the object textural areas is executed by Band $_{N D V I}$ based on area marking using threshold method. In this context brightness function transformation operator is preset:

$$
\begin{gathered}
T H: f(x, y) \rightarrow s(x, y), \\
s(x, y)=\left\{\begin{array}{c}
\lambda_{i} \text { where } T_{i} \leq f(x, y)<T_{i+1}, \\
\lambda_{0} \text { where } f(x, y) \leq T_{0}, \\
\lambda_{k-1} \text { where } f(x, y)>T_{k-1}
\end{array}\right.
\end{gathered}
$$

where $s(x, y)$ is a segmented image, $K$ is a number of segmentation areas, $\lambda_{0}, \lambda_{1}, \ldots, \lambda_{k-1}$ are segmented areas' marks, $T_{0}, T_{1}, \ldots, T_{k-1}$ are threshold values, arranged so that $T_{0}<T_{1}<T_{k-1}$. The values of segmented areas' points correspond to threshold values: $T=0.05,0.1,0.15,0.2, \ldots, 0.7$. As a result an image with averaged values is created, let's denote it as $B_{a n d} d_{N D I}$.

9. Filter the image $\operatorname{Band}_{N D V I}$ (Fig. 2c). Filtration is made for noise damping on the image which appears, in any case, as a result of segmentation. This allows to exclude insignificant inhomogeneous areas on the image with a size of less than 2 pixels for Landsat- 8 data. Median filter used for digital image processing is applied for filtration:

$$
x^{*}=\operatorname{med}\left(y_{1}, y_{2}, \ldots, y_{n}\right) .
$$

As a result Band $_{\text {Filter }}$ image is created.

10. Calculate metric characteristics - for every spatial inhomogeneity on Band $_{\text {Filter }}$ image. 
Square:

$$
S=\frac{1}{2}\left|\sum_{i=1}^{n}\left(X_{i}+X_{i+1}\right)\left(Y_{i}-Y_{i+1}\right)\right|,
$$

where $\left\{\left(X_{i}, Y_{i}\right)\right\}, i=1,2, \ldots, n$ is a sequence of coordinates of adjacent area peaks, $\left(X_{i+1}, Y_{i+1}\right)=\left(X_{1}, Y_{1}\right)$.

Perimeter:

$$
P=\sum_{i=1}^{n} l_{i}
$$

where $l$ is the length of area side, $i=1,2, \ldots, n$ is a number of area sides.

11. Make vector map of spatial inhomogeneities of the object, Fig. $2 d$.

\section{Conclusion}

The article considers problem setting technique for remote monitoring of spatial object based on ERS data, developed by the authors, which generates object feature vector, precisely localizing search area, which enables end user to set information inquiry goal with a minimum number of dialogue steps. Technique is based on a conceptual model of spatial object "AL" with account of its spatial structure. This allows to estimate object state change with time in automatic mode based on feature values' tracing with account of local inhomogeneties. Model implementation on the basis of object-relational approach has been created. End user information inquiry resolution algorithm on remote monitoring of spatial object based on ERS data has been developed as part of the technique.

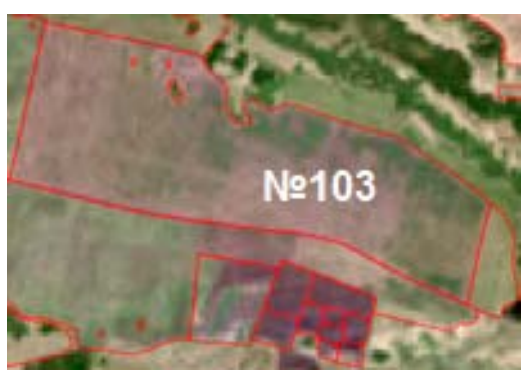

c)

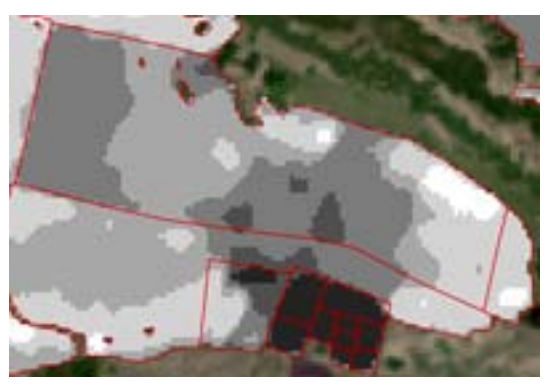

c)

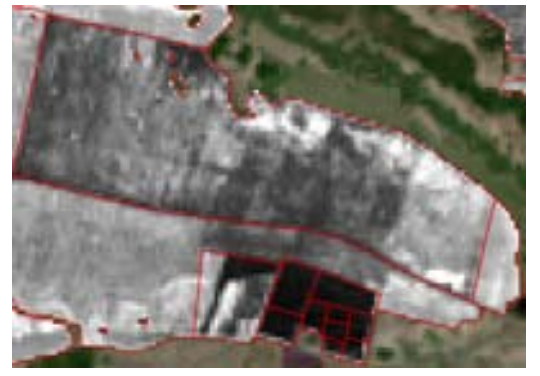

d)

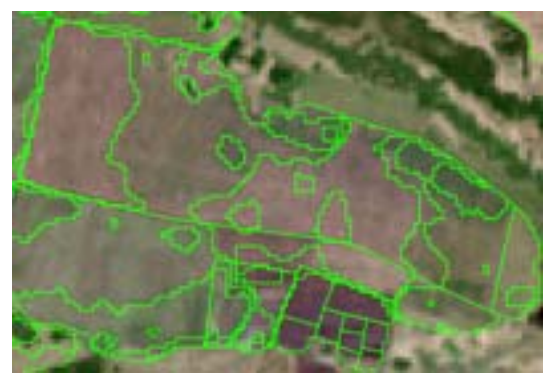

d)

Fig. 2. Results of algorithm steps execution: a) preset object "AL" No.103, b) calculated NDVI index, c) averaged and filtered segment by NDVI values, d) highlighted inhomogeneties for preset object 
Specified results are used in Web-GIS components of agricultural land monitoring system [10-12]. The system was practically tested during research of AL growth dynamics in Sukhobuzimsky District of Krasnoyarsk Krai.

\section{References}

[1] Распоряжение Правительства РФ от 30 июля 2010 г. № 1292-р «О Концепции развития государственного мониторинга земель сельскохозяйственного назначения и земель, используемых или предоставленных для ведения сельского хозяйства в составе земель иных категорий, и формирования государственных информационных ресурсов об этих землях на период до 2020 года» [RF Government Order of July 30, 2010 № 1292-r “On the Concept of development of public monitoring of agricultural land and land used or provided to agriculture as a part of other categories of land, and the formation of state information resources on these lands until 2020 of the year" (in Russian)]

[2] Дибихин К.Ю., Коротков М.А. Распознавание элементов подстилающей поверхности сельскохозяйственного полигона, Многопрофильный университет как региональныий иентр образования и науки, Оренбург, Оренбургский государственный университет, 2009, 587-591 [Dibihin K.Yu., Korotkov M.A. Recognition of the elements of the underlying surface of agricultural landfill, Multidisciplinary University as a regional center of education and science, Orenburg, Orenburg State University, 2009, p.p. 587-591 (in Russian)]

[3] Nikos Pelekis, Babis Theodoulidis, Ioannis Kopanakis and Yannis Theodoridis Literature review of spatio-temporal database models, Cambridge University Press New York, NY, USA, Journal The Knowledge Engineering Review. Volume 19, Issue 3 September 2004, 235-274.

[4] Introduction to Spatio-Temporal Databases [Электронный ресурс]. Режим доступа: http:// www-users.cs.umn.edu/ lmani/spatial/HW5-B4.pdf\#page=4\&zoom=auto,-100,695.

[5] Nandal R. Spatio-Temporal Database and Its Models: A Review. R. Nandal. IOSR Journal of Computer Engineering (IOSR-JCE). 2013. Vol. 11, Issue 2. P. 91-100.

[6] Сапрыкин Е.И., Сладких Л.А., Кулик Е.Н. Оценка состояния посевовзерновых культур по данным дистанционного зондирования Земли, Журнал Интерэкспо Гео-Сибирь, Выпуск № 1, Том 4, 2015, 40-46 [Saprykin E.I., Sladkih L.A., Kulik E.N. Assessment of grain crops based on remote sensing data, Journal Interekspo Geo-Siberia, Issue 1, Vol. 4, 2015, 40-46 (in Russian)]

[7] Шукилович А.Ю., Федотова Е.В., Маглинец Ю.А. Применение сенсора modis для оперативного мониторинга земель сельскохозяйственного назначения, Журнал Сибирского федерального университета, Серия Техника и технологии, 2016, 9(7), 1035-1044 [Shukilovich A.Yu., Fedotova E.V. and Maglinets Yu.A., Using Modis Data for Agricultural Areas Monitoring, Journal of Siberian Federal University. Engineering \& Technologies, 2016, 9(7), 1035 1044 (in Russian)]

[8] Маглинец Ю. А. и Брежнев Р. В., Развитие средств автоматизации приема и обработки спутниковой информации региональной системы ДЗЗ СФУ, Современные проблемы дистанционного зондирования Земли из космоса, 2011, Том 8, № 3, 120-128 [Maglinets Yu.A. and Brezhnev R.V., Automation development of satellite information reception and processing from regional Earth remote sensing system of Siberian Federal University, Modern problems of Earth remote sensing from the Space, 2011, Vol. 8, No. 3, 120-128 (in Russian)]

$$
-826-
$$


[9] Мальцев Е., Маглинец Ю., Брежнев Р., Соснин А., Курносов В. Технология динамического расширения набора атрибутов для поиска пространственных изображений в базе данных, Распознавание образов и анализ изображений 2011, Том 21, № 1, 35-40 [Maltsev E., Maglinets Y., Brejnev R., Sosnin A., Kurnosov V. The technology of dynamic extension of attribute set for the search of satellite images in a data base, Pattern Recognition and Image Analysis, 2011, Vol. 21, No. 1, 35-40 (in Russian)]

[10] Брежнев Р.В., Маглинец Ю.А., Мальцев Е.А., Перфильев С.Е., Сидоров А.Ю., Цибульский Г.М., Шокол А.С. Прогаммно-технологическая инфраструктура информационной поддержки решения задач территориального управления, Журнал Сибирского федерального университета 5 (3), 340-352 (2012) [Brezhnev R.V., Maglinets Yu.A., Mal'tsev E.A., Perfil'ev S.E., Sidorov A.Yu., Tsibul'skii G.M. and Shokol A.S. Software technological infrastructure for information support of territorial control problems, Journal of Siberian Federal University, Engineering \& Technologies, 5 (3), 340-352 (2012) (in Russian)]

[11] Маглинец Ю. А., Мальцев Е. А. И Цибульский Г. М. Многоцелевая геоинформационная система управления территориями Енисейского меридиана, Распознавание образов и анализ изображений , 2012, Том 22, № 2, с. 318-322 [Maglinets Y. A., Mal’tsev E. A., and Tsybul'skii G. M. Multipurpose geoinformation management system of Yenisei meridian territories, Pattern Recognition and Image Analysis, 2012, Vol. 22, No. 2, pp. 318-322 (in Russian)]

[12] Brezhnev R.V., Mal'tsev E.A. An Ontological Spatial Monitoring System for Agricultural Land Monitoring, Pattern Recognition and Image Analysis, 2015, Vol. 25, No. 2, pp. 201-208 